\title{
Managerial Ownership Concentration and Agency Conflict using Logistic Regression Approach: Evidence from Bursa Malaysia
}

\author{
Huson Joher Ali Ahmed \\ Curtin University of Technology Malaysia Campus \\ E-mail: huson.aliahmed@curtin.edu.my
}

\begin{abstract}
s
This paper adopted logit model to examine the relationship between level of managerial ownership concentration and agency conflict which are proxied by level of risk, firms leverage and firms dividend policy. The study covers a period of 5 years from 1997 through 2001. The study is based on the 100 blue-chip stocks, majority of which are derived from CI components. The findings suggest a positive and significant association between level of risk at lower level and managerial ownership while a negative and significant association is also evidenced between risk at higher level and managerial ownership concentration. The debt policy which serves as a positive monitoring substitute for agency conflict is found to be positive and significant explaining the level of ownership concentration. Furthermore, dividend policies, which also serve as monitoring, substitute to reduce agency conflict between manager and external shareholders, do not appear to have any significant impact on managerial ownership. On the other hand, the level of institutional ownership, which serves as an external monitoring force, is found to have inverse impact on level of managerial ownership concentration. This is marginally significant at 10 percent level $(p=.12)$. The findings, in part explain the argument that the managerial ownership help reduce agency conflict between outside equity holders and managers.
\end{abstract}

Keywords: Managerial ownership, Agency conflict, Logistic Regression. 


\section{Acknowledgement}

The author would like to acknowledge the fact that data for this study was extracted from my former MBA student (Shagir).

\section{Introduction}

The issue of managerial ownership and agency conflict has been long-standing interest among academics, researchers due to its strategic impact on firms' value, monitoring of management investment activities. The existence of divergent of interest between the agent and principal is the classical examples of agency relationship. The managerial ownership is assumed to be internal control mechanism and it serves as positive monitoring substitutes to reduce agency conflict. Hence, the level of managerial ownership concentration may have important implication for the conduct of the managers to act at the best interest of principal or maximization of their own value.

The issue has gained popular attention in the recent years after the collapse of Enron, a giant utility firm in the United States the collapse of World.com, a worldwide telecommunication giant in United State. Therefore, it is a question of interest to determine whether managers performs their duty diligently, responsibly for the betterment of shareholders or rather they maximize their very own interest at the expense of shareholders. If not what could be the potential sources of agency conflict? How do theses relate to managerial ownership? Is the managerial ownership served as monitoring substitute to reduce agency conflicts? The seminal work on the issue was first addressed by Jensen and Meckling (1976). They argued that there is a separation of ownership and control in the organizational structure, which creates potential conflict of interest between two parties. Therefore, some form of mechanism are needed to ensure that agent (managers) comply with the guideline provided by principal to maximize the shareholders wealth. They also asserted that certain covenants are also needed to limit management decision on dividend policy and investments (divestitures) undertaking and limitation on the issue of new debt.

The paper is organized as follows. Section 2 briefly highlights the basis for the relationship between managerial ownership by reviewing documented literature. Section 3 briefly highlights hypothesis development. Section 4 provides discussion on data and methodology. While findings and discussions are reported in section 5. Final section summarizes and concludes the paper.

\section{Theory and Evidence}

A body of ideas on the client-agent relation has been advanced under accounting and finance literature. Agency theory, which describes the incentive problems caused by the separation of ownership and controls that resulted the divergence of interest between two parties. The early proponent of the this view was none other than Adam smith (1776) who argued that the company structure generates mismanagement and allow "negligence and profusions of their own servant” which companies were unable to control. Agency Relationship was much later defined by Jensen and Meckling (1976) as a contract under which on or more persons (principal(s) and agent(s)) to perform some service on their behalves which involve delegating some decision making authority to the agent. If the both parties to the relationship are expected to maximize their utility there is a good reason to believe that agent will not act 
the best interest of the principal. The evolution of agency issue is well documented in the literature (Jensen and Meckling, 1976; Watts and Zimmerman, 1978; Miller and Rock 1985). Jensen and Meckling (1976) argue that the divergent of interest and inability of the principals to directly observe the agents action lead to a moral hazard, and an inherent conflict of interest between the principals and the agent which give rise to agency cost. One way to minimize this conflict is to make managers part of the owners.

This can be further illustrated by following:

If manager own 100 percent of the stake he will make operating decision that maximize his utility. However, if the manager does not own the 100 percent of the equity claims on the corporation agency cost will be generated by the divergent of interest between him and those of outside equity holders, since he will only bear a fraction of the cost and any non-pecuniary benefit he takes out in maximizing out his utility. Besides, as the managers' shares of equity fall, their fractional claims on outcome (profit) falls and hence this will tend to encourage them to appropriate larger amount of corporate resources.

The early empirical work on such issue was documented by Demzetz and Lehn (1985). They documented a positive causal relationship between managerial ownership and risk taking. As the proportion of managerial ownership increases, there is a tendency among management to undertake more risky investment, if they assume the pay-off from potential risky investment is higher. Even though there are potential losses from such investment undertaking, it may not result greater losses to managers, as they will bear only the fraction of the losses. However, there are others (Crutchley and Hansen, 1989) who cautioned with the argument that the proven relation could have been spurious. This is further supported by Saunders, Strock, and Travlos (1990) who suggested that the higher managerial ownership might even worsen the agency problems between owners and managers because of higher risk undertaking. Similar studies were also documented by Amihud and Lev (1981) and May (1995). They documented an inverse causal relationship from managerial ownership to risk. While Demsetz (1983) and Heln (1985) contended that firms which operate in risky markets, are more difficult to monitor externally.

Hence, increase in managerial ownership could serve as an internal monitoring device mechanism. The managerial ownership has been argued to be function of o risk taking among the managers. However, more recently, Chen and Steiner (1999) suggested that managerial ownership is to be jointly determined by risk taking, firm's leverage and firms' dividend policy. While on the other front, the documented evidence suggest that determinants of managerial ownership may include risk, debt and dividend in addition to total equity value, research and development.

Jensen and Meckling (1976) argued that the use of debt capital lessen the need for external equity thus raise the proportions of managerial ownership in firm. However, this may prompt creditor intervention when the probability of defaulting on debt covenants increase or when the company needs to be refinanced. Hence the choice of gearing can be thought as bonding mechanism for managerial ownership and likely to reduce the level of managerial ownership as the firm's gearing ratio increases. However, Stulz (1990) indicates that debt levels are positively related to firm value and the extent of imposition of regulation. This is further supported by Friend and Lang (1988) who reported to document a positive causal relation 
from managerial ownership to debt, but also hypothesized that an inverse causality may also proceed from the debt to managerial ownership. But no further explanation was provided. Additionally, payment of debt reduces free cash flows available to manager for perquisites use such as a plush office and corporate condominium. As a result, high level of debt may force mangers to assert more effort to increase shareholders' value rather than engaging in activities that is detrimental to shareholders value.

Moreover, the causal relation from dividends to managerial ownership can be motivated through Jensen (1986)'s free cash flow hypothesis, which argues that the dividend reduce agency cost associated with free cash flow. If the dividend and managerial ownership were served as monitoring substitutes in controlling agency problems of free cash flow, we may expect a negative causal relation from dividends to managerial ownership. Similar expectation can support the causal relation from debt to managerial ownership as Jensen (1986) argues that debt may also serve to reduce the agency cost associated with free cash flow. In a more recently, Chen and Steiner (1999) documented that the firm size which is proxied by market value of the equity, the capital expenditure on $R \& D$ and institutional ownership were found to be determinants of managerial ownership. A negative relationship is expected between firm's size and managerial ownership as the market value increases, the proportion of managerial ownership likely to be decreased. This is very much consistent with the argument proposed by Demsetz and Lehn (1985). Furthermore, Cructley and Hansen (1989) and Jensen, Solberg and Zorn (1992) have developed managerial ownership as the function of $R \& D$ and observed a negative association between managerial ownership and expenditure. However, Cructley and Hansen (1989) reason that the R\&D development expenditure registers the presence of discretionary investment opportunities, which serves as a proxy for greater debt agency cost (Chen and Steiner 1999). Long and Malitz (1985) argued that R\&D expenditure and intangible assets as sources of agency conflict because the mangers can easily use these assets for other risky venture. Besides, Chen and Steiner (1999) documented a negative relationship between the level of institutional ownership and managerial ownership.

This was earlier confirmed by Brickley et al. (1988) and reported that institutional investors serve as positive monitoring role for agency conflict. Hence the presence of institutional investors may further diminish the need for managerial ownership as a mechanism to control for agency cost.

\section{Hypothesis Development}

In summary we test 3 main types of hypotheses namely, risk taking behavior, debt policy and dividend policy. With respect to risk taking behavior, we hypothesized that at higher level of managerial ownership, we expected manager to be more concern about their welfare as welfare of minority shareholders hence a reduction in agency problem is expected. Secondly, we also hypothesized that debt serve as monitoring substitute for firm manager. Hence they will be less motivated to have higher ownership at the presence of debt. Thirdly, with respect to dividend policy, management will be more motivate to distribute higher level of dividends to the shareholders as they can reap this benefit at the expense of debt holders. Hence agency cost may increase further. 


\section{Sample and Methodology}

The study is based on the 100 blue-chip firms listed under first board, KLSE, over a period of 5 years from 1997 to 2001. These 100 companies are mainly derived from the CI components firms. The sample firms were further divided based level of concentration of managerial ownership. The firm, which has managerial ownership concentration of more than $20 \%$, is considered high-end managerial ownership concentration as the study evidenced that average ownership concentration is about $16 \%$. Thus more than 20 are considered a substantial holding in the firms' ownership structure.

\section{Model development}

This study adopted Logistic regression model as the managerial ownership is designed into dichotomy. The model is used to examine whether concentration of managerial ownership is jointly explained by risk taking, debt policy, and dividend policy. Since dependent variable is designed into dichotomy, the use of standard regression techniques (OLS) may be subject to stringent assumptions. Therefore, the use of logistics regression technique as an alternative to OLS based on following reasons:

1. This study uses some form of non-linear variable (such as higher risk level) thus the use of standard multivariate analysis will lead to bias estimation of the parameter.

2. It produces highest accuracy rate (Huson, 2000) for two categories of firms for switching and non-switching auditors.

3. Though neural network is used to examine prediction accuracy among financial state of health, which provides higher prediction accuracy for more complex response variables, logit model provides better prediction accuracy for dichotomous response variable namely high concentration ownership and low concentration ownership.

4. The use of logit model is more robust as it avoids certain assumptions of OLS regression.

\section{The functional form of the Logit model is given by:}

$\mathrm{P}(\mathrm{Y}=1 \mid \mathrm{X})=\exp \left(\sum \beta \mathrm{kXk}\right) /\left[1+\exp \left(\sum \beta \mathrm{k} \mathrm{Xk}\right)\right]$, the parameters are unknown that are estimated by using maximum likelihood estimators (MLE).

Where, $\mathrm{P}\left(\mathrm{Y}_{i}=1 / \mathrm{X}\right)=$ is the probability of higher managerial concentration $\mathrm{X}$

$\operatorname{Exp} \quad=$ is the exponential operator

$\mathrm{Xi} \quad=$ factors that may be associated with managerial ownership

$\beta \mathrm{i} \quad=$ response coefficients

\section{The operational model}

$\mathrm{OWN}=\beta 0+\beta \mathrm{LRISK}+\mathrm{HISKSQ}+\beta \mathrm{DEBT}+\beta \mathrm{DIV}+\beta \mathrm{INST}+\beta \mathrm{ROA}+\beta \mathrm{GRTH}+\beta \mathrm{FIXED}+$ $\beta L I N V+\beta L S I Z E+\beta L V A L+\beta R N D+\varepsilon$

OWN = the level of managerial ownership concentration. It takes value of one if the ratio of officer and directors ownership to total shares outstanding exceeds $20 \%$, zero for otherwise.

The basis for using $20 \%$ as a cut-off point to determine the managerial concentration is based the evidence that average percentage of managerial ownership is reported to be $16 \%$. 
LRISK = standard deviation of the market returns for common stock over 5 years period., a proxy for total risk this measures the risk at lower level.

HRISK = the square of standard deviation of the market returns for common stock over 5 years period., a proxy for total risk. This measures the risk at higher level.

$\mathrm{DIV}=$ ratio of dividends divided by operating income plus one.

$\mathrm{DEBT}=$ Long-term debt to the market value of the equity

INST $=$ the percentage of the share owned by institutional investors.

$\mathrm{ROA}=$ return on asset

RND $=$ the ratio of research and development to total asset

GRTH $=$ Average sale growth rate over a 5 years period

FIXED $=$ measure of the level of fixed asset

LINV = the natural log of the level of capital expenditure

LSIZE = the natural log of the total asset

LVAL = Natural log of the total value of the equity.

\section{Operational Variable}

Ownership which is jointly estimated by level of risk, firms leverage, firms dividend policy, level of market value of equity, level of R\&D to total asset and level of institutional ownership. Ownership is expected to be a positive function of risk at low level of in support of a reduction in conflict between external equity holders and managers. While higher debt and dividend serve to reduce problem with free cash flows (Jensen, 1986), as these variable serve as a monitoring substitute for managerial ownership leading to inverse causal relation from debt and dividend to managerial ownership. Consistent with Demset and Lehn (1985), managerial ownership is expected to be negatively related to total value of the equity. As the share of outside equity increases the proportion of equity hold by manager deems to reduce. Hence, a negative relationship is expected. Similar relation is also expected for institutional ownership.

\section{Statistical Tests}

To measure the relationship between the exogenous variables, and dichotomous response variable, individual estimates is tested as it is tested for ordinary least square.

$\mathrm{t}$-value $=\beta_{\mathrm{k}} / \mathrm{S}-\mathrm{E} \beta_{\mathrm{k}}$ of the coefficient

\section{Goodness of Fit Test}

In normal regression analysis, F-statistics can be used to test the joint hypothesis that all coefficients except intercept are zero. A corresponding test in logit regression that serves the same purpose is based on Likelihood Ratio. The functional form of the likelihood ratio is as follows:

$\lambda_{\mathrm{LR}}=-2\left[\ln \lambda(\beta)-\ln \lambda(\beta)^{*}\right]$

Where,

$\ln \lambda(\beta)$ is the value of the likelihood function for full unrestricted model and $\ln \lambda(\beta) *$ is the maximum value of the likelihood function if all coefficient except the intercept (restricted), are zero. 


\section{Ml Macrothink}

The method produces a statistics that follows approximately a chi-square distribution with $\mathrm{K}-1$ ( $\mathrm{k}$ being the number of independent variable) degree of freedom if joint null hypothesis is true.

\section{Findings and discussions}

\section{Descriptive Statistics}

Table- 1 presents the mean and standard deviation for the selected financial variables. Average managerial ownership is accounted for $16 \%$ with standard deviation of $20 \%$. While the volatility of the stock return is proxied by standard deviation of the returns over 5 years and reported to be $30.4 \%$. The average debt to market value of equity among the blue-chip companies seems to be relatively low in Malaysia recording a ratio of 38\%. The exhibition of lower debt ratio in Malaysia as compared to developed market could be due to two important reasons. Firstly the uncertainty of economic activities over this period has been tremendous when Malaysia experienced worse financial crisis orchestrated by currency devaluation in 1997. Secondly, investors in general tend to be inclined toward equity investment that paves the way for the firms to issue more equity than debt instruments in Malaysia. Beside institutional ownership, which serves as external monitoring device account only $13.5 \%$ of total shareholding, reflecting a large retail investors holding substantial share on Malaysia capital market. While return on asset and turnover growth are $4.10 \%$ and $11.38 \%$ respectively indicating poor performance and slow growth during the analysis period. The dividend to operating income is accounted for $15.9 \%$ with the standard deviation of $35.2 \%$. The average fixed asset to the total asset is accounted for 32.58\%

Table 1: Descriptive statistics of the firm characteristics

\begin{tabular}{|l|l|l|}
\hline Variables & Mean & Stdv \\
\hline OWN & $16 \%$ & $20 \%$ \\
RISK & $30.4 \%$ & $26.00 \%$ \\
DEBT & $28.5 \%$ & $61 \%$ \\
DIV & $15.9 \%$ & $35.25 \%$ \\
INST & $13.5 \%$ & $12 \%$ \\
RND & $2.30 \%$ & $6.00 \%$ \\
ROA & $4.10 \%$ & .08 \\
GRTH & $11.93 \%$ & $26.0 \%$ \\
FIXED & $32.58 \%$ & $24.1 \%$ \\
& & \\
& & \\
\hline
\end{tabular}

\section{Findings of Logit Regression}

To provide objective framework, the agency conflict variables were derived from agency theory and theory of the firms. These are: long-term debt to market value of equity, ratio of dividend to Operating income, standard deviation of stock returns, percentage of institutional ownership, R\&D expenditure. 
Table 2 present the summary results on logistic regression model explaining the relationship between the level of managerial ownership concentrations and agency conflict variables. Thirteen variables were included based on centered data.

Table 2: Logit Regression result

\begin{tabular}{|l|l|l|}
\hline Variables & z-value & Model specification \\
\hline LRISK & $2.393^{* * *}$ & LR- Ratio = \\
HRISK & $-2.293^{* *}$ & Chi-Square = \\
DEBT & $1.862^{*}$ & $22.68 * * *$ \\
DIV & 0.286 & Prediction Rate = \\
INST & $-1.549 \#$ & $73 \%$ \\
ROA & 0.4794 & \\
GRTH & -0.5190 & \\
FIXED & -1.0170 & \\
LINV & 0.3507 & \\
LSIZE & 0.3507 & \\
LVAL & 0.3235 & \\
RND & 0.7606 & \\
CONSTANT & $0-.9163$ & \\
\hline
\end{tabular}

*** indicate level of significant at $5 \%$ level

** indicates level of significant at $10 \%$ level

\# indicates the marginally significant at $10 \%$ level

The level of risk, firms' leverage and dividend policy variables were used to proxy for agency conflict. While level of institutional ownership used as proxy for external monitoring device to oversee the management activities. Initially model includes 12 variables (inclusive of control variables) as the measure to examine the relationship between managerial ownership and agency conflict variables. However, the model retained only four important variables namely level of risk at lower and higher level, debt policy variable and institutional ownership, significant and marginally significant at the conventional level. The likelihood ratio, which is proxied by chi-Square, is used to ascertain the fitness of the model. The chi-square value of 22.68 with 11 degree of freedom indicates model is significant at the conventional level. This supports the notion that there is a clear linkage between managerial ownership concentration and agency conflict variables. While the calculated Pseudo $\mathrm{R}^{2}$ of 18.03 derived from the findings indicates that only $18 \%$ of the cross-sectional variation in managerial ownership could be jointly explained by both agency conflict variables and other control variables. Based on the finding in table 2, the joint hypothesis (all the slope coefficients are simultaneously zero) cannot be accepted. The level of risk in the model is the non-linear function of managerial ownership. The positive and significant parameter for lower level of risk abbreviated by LRisk suggests that at lower level of risk, increase in managerial ownership tends to be reduced the conflict of interest between the manager and external shareholders. However, the negative and significant parameter for higher level of 
risk abbreviated by HRisk suggests that at higher level of risk, managerial risk aversion consideration is expected to limit managerial ownership. This is consistent with study by Chen and Steiner (1999). They consistently demonstrated that at lower level of risk, manager tend to have higher level of ownership concentration. However, at higher level of risk they also demonstrated to have observed negative relationship with the level of ownership concentration. The debt policy variable, which is proxied for monitoring substitutes, appears to be positive and statistically significant at $10 \%$ level. The positive and significant parameter suggests that as the level of long-term debt to market value of equity increases, so does managerial ownership to increase their value at the firms. This is appeared to be consistent with the documented evidence by Stulz (1990) observed that the debt levels are positively related to firm value and the extent of imposition of regulation. This is further supported by Friend and Lang (1988) who reported to document a positive causal relation from managerial ownership to debt, but also hypothesized that an inverse causality may also proceed from the debt to managerial ownership.

While negative and marginally significant parameter for institutional ownership abbreviated by INST is consistent with substitution hypothesis on which higher level of monitoring by institutional investors reduces the value of managerial ownership. This is relatively consistent with positive monitoring effect for institutional ownership identified by Brikley, Lease, and Smith (1988). However, other control variables such as capital expenditure abbreviated by LINV, market value of equity (LVAL) were not found to have any statistical explanation for the managerial ownership.

\section{Summaries and Conclusions}

This study examines whether managerial ownership concentration of the firm could serve as monitoring substitute to reduce agency conflict. Based on the findings from the logit model we found that the risk at lower level is significant and positive relations with managerial ownership concentration. This is consistent with the hypothesis that higher level of managerial ownership can reduce the agency conflict between external equity claimholders and managers. While risk at higher level, appear to have significant and negative relationship with managerial ownership. This is supportive of managerial risk aversion hypothesis. On top of that, the study also evidenced positive and significant association between debt to market value of equity and level of managerial ownership concentration. Finally, the study also observed a negative association between managerial ownership and level of institutional ownership.

\section{References}

Adam Smith. (1776). “Wealth of the Nation” Book-5, Chapter1, pp: 255.

Amihud, Y, \& B.Lev. (1981). “ Risk Reduction as a managerial motive for conglomerate mergers” Bell Journal of Economics, Vol.12, pp.605-607

Brikslyey, J. R.C Leasse \& C.W. Smith Jr. (1988). “ Ownership Structure and Voting of Anti Take-over Amendments”, Journal of Financial Economics, Vol 20, pp.267-291.

Chen., C. and Steiner. T (1999)."Managerial Ownership and Agency Conflict: A Non-Linear Simulteneous Approach“, Journal of Banking and Finance, June, pp.897-924.

Crutchley, Claire \& Robert S. Hansen. (1989). “A test of agency theory of managerial 


\section{Macrothink}

Journal of Management Research

ISSN 1941-899X

2009, Vol. 1, No. 1: E9

ownership, corporate leverage and corporate dividend" Financial Management Vol.18, pp.36-34.

Demsetz, H. (1983). “ The Structure of Ownership and the Theory of the Firm”, Journal of Law and economics, vol, 26, no.2. pp.1155-1177.

Demsets, H. \& K. Lehn, (1985). “The Structure of Corporate Ownership, Causes and Consequences” Journal of Political Economy, vol 93. pp. 1155-1177.

Friend, L. \& LHP. Lang(1988), “An empirical test of the Impact of Managerial Self-Interest on Corporate Capital Structure”, journal of Finance, 43 271-282.

Huson, A.J., Ali, M., Anuar, M.N.., Ariff, M. and Shamsheer M. (2000). Audit Switch Decisions of Malaysian Listed Firms: Test of Determinants of Wealth Effect. Capital Market Review, Malaysia, 8(1\&2), 1-24.

Jensen, M. (1986). Agency Cost of Free Cash flow, Corporate Finance and Takeover, American Economics Review, vol.76, pp.323-329.

Jensen, M.C. \& Meckling, W. (1976). "Theory of the Firm: Managerial behaviour, agency cost and ownership structure” Journal of Financial Economics, vol. 3 no. 4, pp-305-360.

Lang, L. \& Stulz, R.M. (1994). “ Tobin’s q, corporate diversification and firms performance” Journal of Political economy, vol.102 no.6, pp.1248-1280

Miller, M., \& K. Rock (1985). “Dividend Policy Under Asymmetric Information” Journal of Finance, pp: 1031-1052.

Saunders, A., F. Stock, \& N.Travlos, (1990). “Ownership Structure, deregulation, and bank risk-taking” journal of financial research vol.5 pp: 249-259.

Smith

Stulz, R. (1990). “ Mangerial discretion and optimum financing policies” Journal of financial economics, vol.26 pp.2-27.

Watt,R.L. \& Zimmerman (1978). "Positive Accounting Theory: A Ten Years Perspective” The Accounting Review, Vol.65, pp: 31-156. 